\title{
HPV infection and immunochemical detection of cell-cycle markers in verrucous carcinoma of the penis
}

\author{
Elzbieta Stankiewicz ${ }^{1}$, Sakunthala C Kudahetti ${ }^{1}$, David M Prowse ${ }^{1}$, Elena Ktori ${ }^{1}$, \\ Jack Cuzick ${ }^{2}$, Laurence Ambroisine ${ }^{2}$, Xiaoxi Zhang ${ }^{1}$, Nicholas Watkin ${ }^{3}$, \\ Catherine Corbishley ${ }^{3}$ and Daniel M Berney ${ }^{1}$
}

${ }^{1}$ Centre for Molecular Oncology and Imaging, Barts and The London School of Medicine and Dentistry, London, UK; ${ }^{2}$ Cancer Research UK Centre for Epidemiology, Mathematics and Statistics, Wolfson Institute of Preventive Medicine, Barts and The London School of Medicine and Dentistry, Queen Mary, University of London, London, UK and ${ }^{3}$ The Cellular Pathology Department, St George's Hospital, Tooting, London, UK

\begin{abstract}
Penile verrucous carcinoma is a rare disease and little is known of its aetiology or pathogenesis. In this study we examined cell-cycle proteins expression and correlation with human papillomavirus infection in a series of 15 pure penile verrucous carcinomas from a single centre. Of 148 penile tumours, $15(10 \%)$ were diagnosed as pure verrucous carcinomas. The expression of the cell-cycle-associated proteins p53, p21, RB, p16 ${ }^{\mathrm{NKK} 4 \mathrm{~A}}$ and Ki67 were examined by immunohistochemistry. Human papillomavirus infection was determined by polymerase chain reaction to identify a wide range of virus types. The expression of p16 $6^{\mathrm{INK} 4 \mathrm{~A}}$ and Ki67 was significantly lower in verrucous carcinoma than in usual type squamous cell carcinoma, whereas the expression of p53, p21 and RB was not significantly different. p53 showed basal expression in contrast to usual type squamous cell carcinoma. Human papillomavirus infection was present in only 3 out of 13 verrucous carcinomas. Unique lowrisk, high-risk and mixed viral infections were observed in each of the three cases. In conclusion, lower levels of p16 INKAA and Ki67 expressions differentiate penile verrucous carcinoma from usual type squamous cell carcinoma. The low Ki67 index reflects the slow-growing nature of verrucous tumours. The low level of p16 INK4A $^{\mathrm{A}}$ expression and human papillomavirus detection suggests that penile verrucous carcinoma pathogenesis is unrelated to human papillomavirus infection and the oncogenes and tumour suppressor genes classically altered by virus infection.
\end{abstract}

Modern Pathology (2009) 22, 1160-1168; doi:10.1038/modpathol.2009.77; published online 22 May 2009

Keywords: penile verrucous carcinoma; human papillomavirus; p53; p21; p16 ${ }^{\text {INK4A; }}$ RB

Verrucous carcinoma is a rare low-grade squamous cell carcinoma with slow invasive growth and lack of metastasis. It was first described in 1948 by Lauren V Ackerman in the oral cavity. ${ }^{1}$ Since then it also has been described at other sites, including the anus, female genitalia and penis. ${ }^{2-4}$ Grossly, verrucous carcinomas are exophytic white-grey papillomatous neoplasms. Microscopically, hyperkeratosis, papillomatosis and acanthosis are present; koilocytosis is absent. The cells are extremely well

Correspondence: Dr DM Berney, MB, BChir, MA FRCPath, Barts and The London School of Medicine and Dentistry, Queen Mary, University of London, Centre for Molecular Oncology and Imaging, Institute of Cancer, John Vane Science Centre, Charterhouse Square, London EC1M 6BQ, UK.

E-mail: D.Berney@bartsandthelondon.nhs.uk

Received 25 November 2008; revised and accepted 21 April 2009; published online 22 May 2009 differentiated with prominent intercellular bridges. The base of the tumour is broad, with pushing, regular borders composed of broad bulbous projections. $^{5-8}$

Squamous cell carcinoma of the penis is itself rare and represents $0.3-0.5 \%$ of male malignancies in Europe and the United States of America. ${ }^{9}$ The most common type of penile squamous cell carcinoma is the usual type (70\%), followed by basaloid (10\%) and a heterogenous group of 'verruciform' tumours $(20 \%) .{ }^{5}$ However, mixed tumours commonly exist of usual type squamous cell carcinoma and one or more type of verruciform tumour. Verruciform lesions include verrucous carcinoma, warty carcinoma (also known as Buschke-Lowenstein tumour (BLT) or giant condyloma accuminatum) and papillary squamous cell carcinoma, not otherwise specified. $^{8,10}$ The reported frequency of penile verrucous carcinoma is low and accounts for 
Table 1 Pathologic and clinical features for pure penile verrucous carcinomas

\begin{tabular}{|c|c|c|c|c|c|c|c|c|}
\hline $\begin{array}{l}\text { Patient } \\
\text { number }\end{array}$ & $\begin{array}{c}\text { Patient } \\
\text { age }\end{array}$ & Surgery type & $\begin{array}{l}\text { Width } \\
(\mathrm{mm})\end{array}$ & $\begin{array}{c}\text { Depth } \\
\text { (mm) }\end{array}$ & $\begin{array}{l}\text { Type of } \\
\text { growth }\end{array}$ & $\begin{array}{l}\text { Tumour } \\
\text { grade }\end{array}$ & $\begin{array}{c}\text { Tumour } \\
\text { stage }\end{array}$ & $\begin{array}{l}\text { Presence } \\
\text { of } B X O\end{array}$ \\
\hline 1 & 50 & Glansectomy & 22 & 3 & Endophytic & 2 & 1 & No \\
\hline 2 & 73 & Glansectomy & 11 & 3 & Mixed & 1 & 1 & No \\
\hline 3 & 81 & Distal penectomy & 42 & 40 & Mixed & 1 & 2 & No \\
\hline 4 & 74 & Glansectomy & 14 & 3 & Exophytic & 1 & 2 & No \\
\hline 5 & 71 & Glans excision biopsy & 15 & 6 & Endophytic & 1 & 2 & Yes \\
\hline 6 & 84 & Glansectomy & 22 & 14 & Exophytic & 1 & 1 & No \\
\hline 7 & 35 & Circumcision & 25 & 2.4 & Exophytic & 1 & 1 & No \\
\hline 8 & 73 & Radical penectomy & 80 & 14 & Exophytic & 2 & 1 & No \\
\hline 9 & 60 & Glansectomy & 17 & 7 & Exophytic & 1 & 2 & No \\
\hline 10 & 81 & Glansectomy & 20 & 7 & Exophytic & 1 & 2 & Yes \\
\hline 11 & 88 & Glansectomy & 24 & 8 & Exophytic & 2 & 2 & No \\
\hline 12 & 61 & Glansectomy & 13 & 1 & Exophytic & 1 & 1 & No \\
\hline 13 & 66 & Partial glansectomy & 36 & 8 & Exophytic & 1 & 1 & Yes \\
\hline 14 & 35 & Glansectomy & 25 & 4 & Exophytic & 1 & 1 & No \\
\hline 15 & 63 & Glansectomy & 27 & 17 & Endophytic & 1 & 2 & No \\
\hline
\end{tabular}

$3-20 \%$ of all penile cancers. ${ }^{5,6,11-13}$ However, identification of cases from the literature is sometimes difficult because of the varied nomenclature used in the past, often regarding them as the same lesion as BLT. ${ }^{14,15}$ Risk factors for penile verrucous carcinoma seem to be similar as for penile cancer in general, which are poor hygiene, phimosis and chronic inflammation ${ }^{16}$ but no systematic case series has been studied. The human papillomavirus (HPV) role in pathogenesis of these tumours is not certain because of small number of cases available for studies. One large study on penile cancer has found verrucous carcinoma to be always associated with squamous hyperplasia. ${ }^{17}$ The treatment of choice for penile verrucous carcinoma is similar to verrucous cases from other sites and involves wide surgical excision, less commonly, radiation or chemotherapy. ${ }^{4,18}$ Untreated or inadequately excised verrucous carcinoma can progress locally but distant metastasis are exceptional. ${ }^{5,16}$ The rarity of the disease makes it difficult to study, and mostly case reports or studies on small series are available.

The aim of this project was to study the HPV status in penile verrucous carcinomas and its potential association with the immunohistochemical detection of key cell-cycle proteins: p53, p21, p16 $6^{\mathrm{INK} 4 \mathrm{~A}} \mathrm{RB}$ and Ki67 to elucidate their pathogenesis.

\section{Materials and methods}

We retrospectively retrieved 148 penile squamous cell carcinomas from the Cellular Pathology Department of St George's Hospital. Of the samples, 29 were penile verruciform tumours-15 pure verrucous carcinomas and 14 mixed type-which we excluded from our study. Other squamous cell carcinoma types were usual type (97), basaloid (17) and warty (5). The tumours were obtained from circumcision excision biopsy, glansectomy or penectomy. They were graded into groups as: well (grade 1), moderately (grade 2) and poorly differentiated (grade 3) on the degree of the cytological pleomorphism, mitotic rate and architectural atypia. For stage, the TNM (2002) classification of penile cancer was used. ${ }^{19}$ The key pathologic and clinical features are listed in Table 1. Results from the penile verrucous carcinomas were compared with those from usual type squamous cell carcinomas.

\section{Immunohistochemistry}

Tissue microarray blocks were prepared using a manual microarrayer. Tissue cores $(3 \times 1 \mathrm{~mm})$ were taken from each tissue sample. Tissue sections were cut at $4 \mu \mathrm{m}$ thickness. A heat-induced antigen retrieval method with citrate buffer pH6.0 was applied. Immunochemistry was performed using the avidin-biotin technique with the antibodies against p53 (Dako; M7001), p21 (Dako; M7202), RB (Novocastra; NCL-RB-358), p16 ${ }^{\mathrm{INK} 4 \mathrm{~A}}$ tumour suppressor protein (Neomarkers, MS-1064-PO) and Ki67 (Dako; A0047). Dilutions were as follows: p53 and p21 1:1000, RB 1:50, p16 $6^{\mathrm{INK} 4 \mathrm{~A}}$ and Ki67 1:100. The positive controls were: CIN III for p16 $6^{\text {INK4A }}$ placenta for p21, anaplastic thyroid cancer for p53 and tonsil for RB and Ki67. The immunohistochemistry results are summarized in Table 2. Examples of immunostaining are shown in Figure 1. The staining pattern in case of p53, p21, RB and Ki67 was nuclear. p16 ${ }^{\mathrm{INK} 4 \mathrm{~A}}$ showed both nuclear and cytoplasmic staining. Results were compared with expression in usual type squamous cell carcinomas.

Sections were scored semiquantitatively by a consultant genitourinary pathologist (DB). For nuclear positivity each core was given an estimated visual score as $0-100 \%$, representing the percentage of positively stained neoplastic nuclei. Nuclear score alone was applied to assess p53 and Ki67 expression (as expression was always strong). For nuclear expression of p16 ${ }^{\mathrm{INK} 4 \mathrm{~A}} \mathrm{RB}$ and $\mathrm{p} 21$ antibody, the intensity of staining was also measured using 
Table 2 Immunohistochemistry and PCR results for pure penile verrucous carcinomas

\begin{tabular}{|c|c|c|c|c|c|c|c|}
\hline $\begin{array}{l}\text { Verrucous } \\
\text { sample }\end{array}$ & $\begin{array}{c}\text { Nuclear p16 } \\
(0-300)\end{array}$ & $\underset{(0-3)}{\text { Cytoplasmic p16 }}$ & $\begin{array}{c}R B \\
(0-300)\end{array}$ & $\begin{array}{c}p 53 \\
(0-100)\end{array}$ & $\begin{array}{c}p 21 \\
(0-300)\end{array}$ & $\begin{array}{c}\text { Ki67 } \\
(0-100)\end{array}$ & $\begin{array}{l}\text { HPV type } \\
\text { detected }\end{array}$ \\
\hline 1 & 40 & 1 & 270 & 1 & 40 & 30 & - \\
\hline 2 & 0 & 0 & 240 & 5 & 5 & 10 & - \\
\hline 3 & 0 & 0 & 180 & 5 & $\mathrm{ND}^{\mathrm{a}}$ & 10 & $\mathrm{ND}^{\mathrm{b}}$ \\
\hline 4 & 0 & 0 & 270 & 60 & 0 & 10 & - \\
\hline 5 & 0 & 0 & 270 & 5 & 20 & 20 & - \\
\hline 6 & 0 & 0 & 240 & 5 & 10 & 20 & - \\
\hline 7 & 0 & 0 & 240 & 10 & 10 & 20 & 51,52 \\
\hline 8 & 0 & 1 & 240 & 10 & 20 & 20 & - \\
\hline 9 & 0 & 0 & 210 & 40 & 40 & 30 & $\mathrm{ND}^{\mathrm{b}}$ \\
\hline 10 & 0 & 0 & 270 & 40 & $\mathrm{ND}^{\mathrm{a}}$ & 10 & $31,33,44,45$ \\
\hline 11 & 0 & 0 & 300 & 10 & 5 & 20 & - \\
\hline 12 & 0 & 0 & 270 & 10 & 0 & 20 & - \\
\hline 13 & 0 & 0 & 240 & 0 & 1 & 10 & - \\
\hline 14 & 0 & 0 & 240 & 10 & 60 & 30 & 11 \\
\hline 15 & 0 & 0 & 240 & 20 & 20 & 30 & - \\
\hline
\end{tabular}

$(-)$ in the last column indicate HPV-negative.

${ }^{\mathrm{a}} \mathrm{ND}$ : lack of data due to random tissue loss from tissue microarray.

${ }^{\mathrm{b}} \mathrm{ND}$ : lack of data due to inadequate DNA.

the scores: 1 (low), 2 (medium) and 3 (high). The final score was deduced by multiplying the percentage of staining by intensity to give an expression score from 0 to 300. Cytoplasmic expression of p16 ${ }^{\mathrm{INK} 4 \mathrm{~A}}$ was determined by intensity of staining alone. The core with highest score was chosen for each patient for analysis.

Statistical analysis was performed using StatsDirect software, version 2.60.6000. The correlations between antibodies were evaluated using Spearman's test. The association between the antibody and the tumour subtype or HPV infection was evaluated by $\chi^{2}$-test. Where the number of patients was low, Fisher's exact probability test was used. The cut-off points for antibodies were as follows: $>0$ for $\mathrm{p} 16^{\mathrm{INK} 4 \mathrm{~A}}, \geq 5 \%$ for $\mathrm{p} 53$ and $\mathrm{p} 21, \geq 20 \%$ for Ki67 and $\geq 240$ for high expression of RB. In all analyses $P<0.05$ was considered to be statistically significant.

\section{HPV Analysis}

A total of 13 original wax blocks from verrucous carcinoma cases were suitable for DNA extraction. DNA was extracted with a QIAamp DNA Mini kit (catalogue no. 51304; Qiagen, Crawley, UK). $\beta$ Globin polymerase chain reaction (PCR) was performed using primers B1 and B19 to confirm the adequacy of the extracted DNA. Validated samples were tested for the presence of HPV DNA by a broadspectrum HPV PCR method using SPF10 primers, which amplify a 65-bp fragment of the L1 open reading frame and HPV genotypes identified by the INNO-LiPA line probe assay (Innogenetics NV, Ghent, Belgium). ${ }^{20}$ As a positive control, a known HPV-positive cervical cancer sample was used. Mouse tissue served as negative control. To ensure specificity of the method negative samples were included alongside every 5-10 regular samples.

\section{Results}

\section{Immunohistochemistry}

p53

p53 expression in penile verrucous carcinomas was present in $87 \%(13 / 15)$ tumours, mostly confined to the basal or suprabasal layers, which contrasted with more diffuse patterns in usual type squamous cell carcinomas (Figure 1a). The percentage of positive-cell nuclei varied from 0 to $60 \%$, with a mean of $15 \%$ and median of $10 \%$. No significant difference in p53 expression was observed between penile verrucous carcinomas and usual type penile squamous cell carcinomas $(P=0.7326)$.

p21

p21 was positive in $77 \%(10 / 13)$ of patients. The percentage of p21 stained cells was usually low and the intensity was weak (Figure 1b). The calculated expression scores for p21 expression in penile verrucous carcinomas ranged from 0 to 60 with mean of 18 and median 10 . The expression of p21 in penile verrucous carcinomas was not significantly different from that in usual type penile squamous cell carcinomas $(P>0.9999)$.

\section{$R B$}

$\mathrm{RB}$ expression in verrucous carcinomas was often strong and involved $60 \%$ and more nuclei (Figure 1c). It was strongly positive in $87 \%(13 / 15)$ of cases. RB expression varied from a score of 180 to 300 with mean of 248 and median of 240 . There was a trend for higher RB expression in penile verrucous carcinomas than usual type squamous cell carcinomas $(P=0.0441)$.

p16 ${ }^{I N K 4 A}$

Expression of nuclear $\mathrm{p} 16^{\mathrm{INK} 4 \mathrm{~A}}$ in verrucous carcinomas was not detected in 14 of 15 samples 

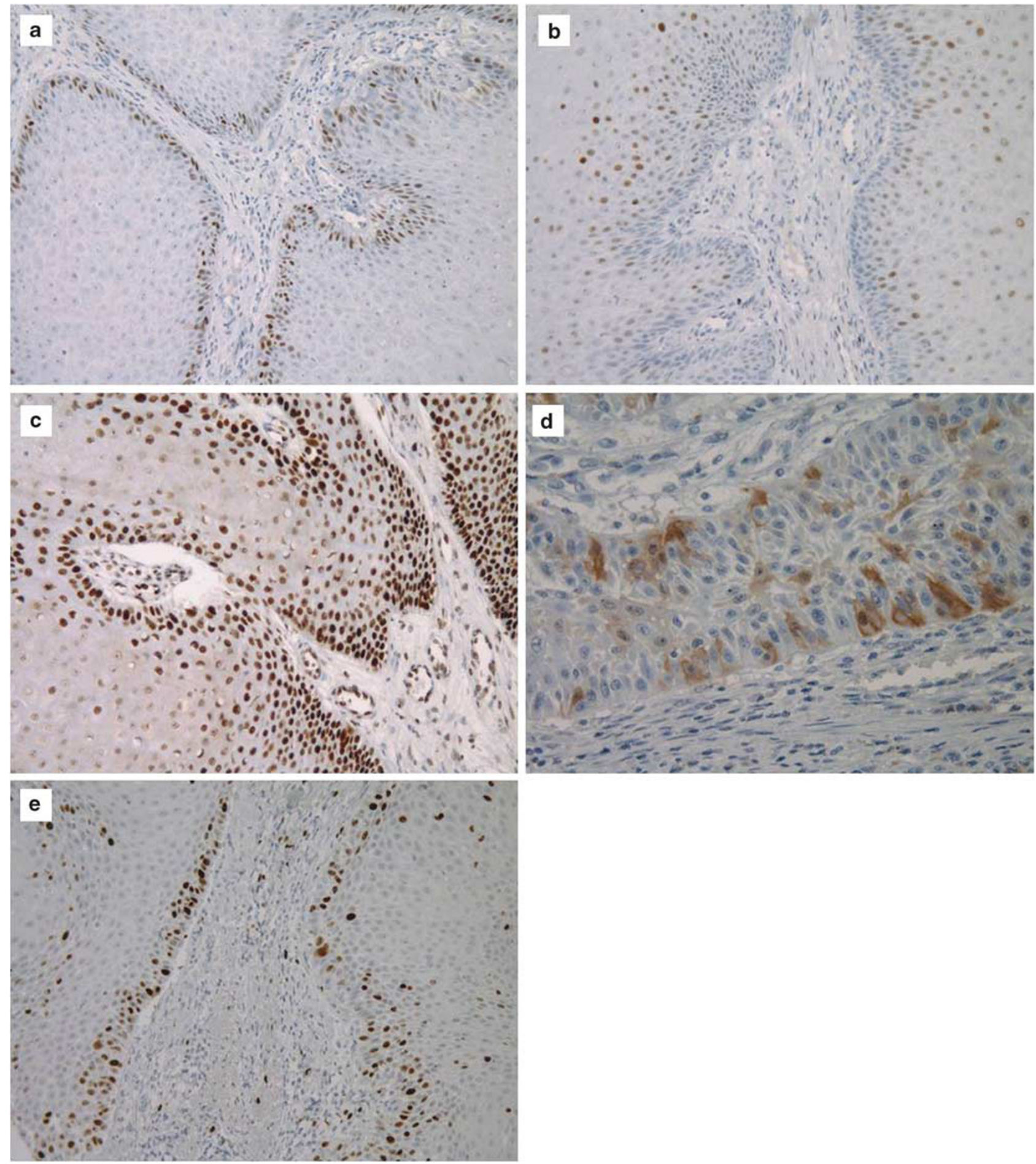

Figure 1 Immunostaining results for penile verrucous carcinoma. (a) Strong positivity of p53 in basal areas of the tumour. (b) p21 expression, showing scattered staining only. (c) Strong RB expression throughout the tumour, (d) p16 ${ }^{\mathrm{INK} 4 \mathrm{~A}}$ expression showing both cytoplasmic and nuclear positivity. (e) Supra-basal nuclear positivity for Ki67 expression. All pictures magnification: $\times 200$.

(93\%). Only 1 sample was positive with an expression score of 40. Cytoplasmic expression of $\mathrm{p} 16^{\mathrm{INK} 4 \mathrm{~A}}$ was also absent in most of the samples with only two samples weakly stained (Figure 1d). There was a significant difference in p16 ${ }^{\mathrm{INK} 4 \mathrm{~A}}$ nuclear $(P=0.0019)$ and cytoplasmic $(P=0.019)$ expression between penile verrucous 
cases. The level of expression varied from a minimum of 10 to a maximum of $30 \%$ of positively stained neoplastic nuclei, with a mean of $19 \%$ and median of $20 \%$. Ki67 expression in penile verrucous carcinomas was significantly lower than that seen in usual type penile squamous cell carcinomas $(P=0.0108)$.

\section{HPV Infection}

HPV DNA was present in 3 out of 13 (23\%) of penile verrucous carcinoma cases studied. Low-risk (HPV 11), high-risk (HPV 51, 52) and mixed HPV infections $(31,33,44,45)$ were observed in the verrucous carcinomas. None of verrucous cases contained high-risk HPV 16 type, which was the most common type in usual type penile squamous cell carcinomas.

\section{Discussion}

Penile verrucous carcinoma is extremely rare, not well characterized and its aetiology poorly understood. In early studies, association with HPV infection had been made, especially low-risk types 6 and 11, but confusion over classification of verruciform tumours often resulted in regarding verrucous carcinoma as one entity with BLT $^{21}$ clouding the evidence. Other authors suggested that screening for HPV may help in differentiating verrucous carcinoma from BLT, as verrucous carcinoma has been found to be negative for HPV infection. ${ }^{22-28}$ However, those studies often utilized for HPV detection the in situ hybridization method, which is not as sensitive as PCR. ${ }^{29}$ A review of literature on HPV infection in penile verrucous carcinoma is presented in Table 3. In general, regardless of the detection method, verrucous carcinoma is still considered as cancer not related to HPV infection. ${ }^{12,13,30,31}$ We used a broad-spectrum HPV PCR method with SPF10 primers which amplify a 65-bp fragment of the L1 open reading frame and HPV genotypes identified by the INNO-LiPA line probe assay. This method is considered as highly specific and extremely sensitive for the simultaneous detection of multiple HPV types in clinical samples, including formalinfixed, paraffin-embedded material. ${ }^{32}$ We detected HPV DNA in $23 \%(3 / 13)$ of penile verrucous carcinomas and in 59\% (38/64) of usual type squamous cell carcinomas. None of the HPVpositive verrucous cases contained HPV16 type, whereas it was the most prevalent type in usual type squamous cell carcinomas. Two authors of this article applied the same method before on an independent cohort (from the Barts and the London NHS Trust) of penile squamous cell carcinomas, penile lichen sclerosus and late stage cervical carcinoma with HPV positivity of 33, 54 and $92 \%$, respectively. ${ }^{20}$ According to the largest study of HPV infection in penile cancer by Rubin et $a l^{33}$ only basaloid and warty types of penile squamous cell carcinoma are consistently associated with HPV, whereas in verrucous and usual type squamous cell carcinomas, HPV infection is present only in 33.3 and $34.9 \%$ of cases, respectively. They included 106 keratinizing, 15 basaloid, 12 verrucous and 5 warty cases. Our results for verrucous cases confirm the low incidence of HPV infection in this cancer type. Within three HPVpositive verrucous carcinoma cases, one contained low-risk HPV, one only high-risk types and the third one mixed low and high-risk HPV types. Both low- (HPV 11) and high-risk (HPV 16 and 52) types have been reported previously in verrucous cases, including the Rubin et al study, ${ }^{33}$ where they found high-risk HPV in two of their four HPVpositive verrucous cases.

p53 is a tumour suppressor protein, commonly inactivated in cancer by mutation, leading to its accumulation in transformed cells. However, in HPV related cancers, expression of viral E6 protein is known to inactivate p53 through its downregulation. Therefore, an inverse correlation between HPV

Table 3 Summary of published data on penile verrucous carcinoma associated with HPV infection

\begin{tabular}{|c|c|c|c|c|}
\hline Reference & Method & detection range & HPV detected & No/total (\%) \\
\hline Kiyabu et $a l^{22}$ & PCR & HPV 16, 18 & 0 & $0 / 3(0)$ \\
\hline Villa and Lopes ${ }^{26}$ & Southern blot & HPV6, 11, 16, 18 & 0 & $0 / 1(0)$ \\
\hline \multirow[t]{2}{*}{ Varma et $a l^{27}$} & ISH & HPV6, 11, 16, 18, 31, 33, 35 & 0 & $0 / 4(0)$ \\
\hline & PCR & HPV6, 11, 16 & 0 & $0 / 4(0)$ \\
\hline Higgins et $a l^{28}$ & ISH & HPV6, 11, 16, 18, 31, 33 & 0 & $0 / 5(0)$ \\
\hline Masih et $a l^{23}$ & Isotopic ISH & HPV 6, 11, 16, 18, 31 & 0 & $0 / 10(0)$ \\
\hline Chan et $a l^{13}$ & PCR & HPV 16, 18 & 0 & $0 / 7(0)$ \\
\hline Cupp et $a l^{31}$ & PCR & HPV 16, 18 & 0 & $0 / 3(0)$ \\
\hline Dianzani et $a l^{48}$ & PCR & HPV $6,11,16,18,31,33$ & HPV11 & $1 / 1(100)$ \\
\hline Rubin et $a l^{33}$ & PCR & Wide range, SPF 10 primers & HPV6, 16, other & $4 / 12(33.3)$ \\
\hline Ferreux et $a l^{47}$ & PCR & Wide range & HPV6 & $1 / 1(100)$ \\
\hline \multirow[t]{2}{*}{ Seneba et $a l^{29}$} & ISH & HPV6, 11, 16, 18, 31, 33 & HPV6 & $1 / 1(100)$ \\
\hline & PCR & Wide range, SPF 10 primers & HPV6 & $1 / 1(100)$ \\
\hline Wong et $a l^{49}$ & Not specified & & HPV6 & $1 / 1(100)$ \\
\hline Stankiewicz et al (current study) & PCR & Wide range, SPF 10 primers & HPV 11, 31, 33, 44, 45, 51, 52 & $3 / 13(23)$ \\
\hline
\end{tabular}

PCR, polymerase chain reaction; ISH, in situ hybridization. 
positivity and p53 overexpression has been suggested, with special regards to cervical, vaginal and vulvar carcinomas. ${ }^{34}$

We used clone DO-7 p53 antibody, which preferentially detects mutated p53 protein or high levels of wild-type protein. We detected p53 expression in $87 \%(13 / 15)$ of the penile verrucous carcinomas, which was similar to the usual type squamous cell carcinomas, but the percentage of stained cells was low (in most cases only $5-10 \%$ of cells stained). Most of the staining was basal or suprabasal in nature. There was no negative correlation between HPV infection and p53 expression in usual type or verrucous carcinomas; in fact all three HPV-positive verrucous cases were also p53-positive. Lam and Chan $^{35}$ have detected a higher p53 expression using a similar method and the same antibody clone. All 5 cases of their penile verrucous carcinomas and 89\% of usual type squamous cell carcinomas were p53positive, also mostly in basal cells. Similar to our study, they did not observe an inverse correlation between HPV and p53 overexpression. Another study by the same authors ${ }^{30}$ has shown no p53 expression in all seven verrucous cases studied and only in $49 \%$ of usual type squamous cell carcinomas. The explanation could be in a higher cut-off point used in that study. Ouban et al ${ }^{36}$ detected weak, scattered p53 expression in penile verrucous carcinomas, which was lower than in usual type squamous cell carcinomas, expressing strong nuclear staining. These verrucous carcinomas also overexpressed MDM2 protein, which could explain p53 downregulation, as MDM2 is a p53-negative regulator. Adegboyega et $a l^{37}$ detected p53 only in the lower third of epithelium in their mixed series of 19 verrucous carcinomas from different sites, including 3 cases of penile verrucous carcinoma, whereas usual type squamous cell carcinomas showed the stained cells through the entire thickness of the epithelium. Pilotti et al, ${ }^{24}$ who studied five cases of vulvar verrucous carcinoma and two cases of BLT, did not detect p53 in verrucous carcinoma samples. Similarly, Gualco et al ${ }^{3}$ did not find p53 (mutated or wild type) or HPV infection in their series of 10 cases of vulvar verrucous carcinoma, which in their opinion confirmed the low malignant behaviour of this lesion. The discrepancies in p53 expression in verrucous carcinoma may be the result of the limited number of samples available for study. The differences in tissue fixation or antigen retrieval methods could also influence the outcome. Furthermore, considering complexity of p53 pathway and its diverse regulatory mechanisms, any changes in physiological conditions within the tissue may greatly affect expression levels and activity of wild-type protein and its mutant forms at a given time. ${ }^{38}$ Ideally, additional study of mutations within the p53 gene would confirm the mutational status of p53 in those samples.

Our series of penile verrucous carcinomas is the largest studied and suggests that p53 overexpression is common in penile verrucous carcinoma and is not affected by HPV infection. However, similar to other studies, the percentage of p53-positive cells is not high.

p53 regulates expression of another important protein in cell-cycle control, p21. p21 is a CDK inhibitor which is upregulated by p53 in response to DNA damage and causes cell-cycle arrest. p21 is rarely overexpressed in human cancers. Loss of p21 expression as well as overexpression has been related to poor prognosis in some cancers. ${ }^{39}$ In this study, we detected p21 expression in 77\% (10/13) of penile verrucous carcinoma at low levels. Lam and Chan ${ }^{35}$ detected p21 in $40 \%$ of penile squamous cell carcinomas, including all five cases of verrucous carcinoma; however, staining was weak, similar to our study. They also noted an inverse correlation between p21 and p53 in half of the squamous cell carcinomas and four of five verrucous carcinomas, which is in agreement with the existence of a negative feedback loop between p53 and p21 expression. ${ }^{40}$ Among our cases we found two tumours p21-/p53+ and 1 tumour p21+/p53-, however, there was no correlation between p53 and p21 expressions. This might be explained by the possible induction of p21 in a p53 independent way. ${ }^{41}$ Adegboyega et $a l^{37}$ found p21 expression in all 19 cases of verrucous carcinoma from different sites and it was expressed either in lower third of epithelium (58\%) or through the entire thickness of the epithelium (42\%). Our results for p21 expression in penile verrucous carcinoma are higher than those in the above-mentioned studies and might be more accurate as our series included 15 penile verrucous carcinoma to compare with 5 cases from the Lam and Chan ${ }^{35}$ study or 3 penile verrucous carcinoma from the Adegboyega et al report. ${ }^{37}$

One of the main functions of p21 is p53dependent cell-cycle arrest, which should lead to decreased proliferation. Surprisingly, we found a positive correlation between p21 and the proliferation marker Ki67 in verrucous carcinoma $(P=0.0003)$. Cheung et $a l^{42}$ found in cervical cancer a positive correlation of $\mathrm{p} 21$ with advanced tumour stage. He suggested that increase in p21 expression represented an ineffective cellular response to increased cellular activity and did not contribute to tumour development. A positive correlation between p21 and Ki67 in squamous cell carcinomas of the skin from sun-exposed and anogenital sites has also been reported and p21 function linked to cell differentiation. ${ }^{43}$

Another tumour suppressor protein involved in cell-cycle control and progression is the retinoblastoma protein (RB). In its active, hypophosphorylated state, it binds E2F proliferation factors and inhibits the cell passage through the $G_{1}$ restriction point and entering the S phase. RB mutations, consistent with loss of RB function, have been identified in a wide spectrum of cancers. In tumours infected with HPV, $\mathrm{RB}$ is often inactivated and downregulated by viral 
E7 protein. ${ }^{44}$ In our verrucous carcinoma series all tumours studied for HPV infection highly expressed RB protein. In general, we found high expression of $\mathrm{RB}$ in $87 \%(13 / 15)$ of verrucous carcinomas, which most probably reflects normal cell responses to increased proliferation during tumuorigenesis and confirms the lack of HPV involvement in RB regulation in this particular cancer. In contrast, we found an inverse correlation between HPV infection and RB protein expression in usual type squamous cell carcinomas (unpublished data), suggesting a different aetiology for those tumours. To our knowledge there is no other RB study on penile verrucous carcinoma apart from Adegboyega et $a{ }^{37}$ who included three penile cases in their verrucous carcinoma series and found high RB expression in $95 \%$ of tumours, which is very similar to our results. p16 ${ }^{\text {INK4A }}$ tumour suppressor protein is a CDK4 inhibitor and its expression can prevent cell-cycle progression by inhibiting the phosphorylation of RB. p16 ${ }^{\text {INK4A }}$ is commonly not expressed in the tumour cells due to homozygous deletion, mutations or promoter methylation. ${ }^{45}$ However, in tumours with HPV infection, accumulation of $\mathrm{p} 16^{\mathrm{INK} 4 \mathrm{~A}}$ is a well-known event in response to RB inactivation by viral E7 protein. ${ }^{46}$ We detected a lack of p16 ${ }^{\text {INK4A }}$ nuclear and cytoplasmic expression in our penile verrucous carcinoma series in $93 \%(14 / 15)$ and $87 \%$ (13/15) of cases, respectively. Ferreux et $a l^{47}$ found at least three alternative mechanisms targeting the $\mathrm{p} 16^{\mathrm{INK} 4 \mathrm{~A}} /$ cyclin D/RB pathway in penile carcinoma. One of them involved p16 ${ }^{\text {INK4A }}$ overexpression found in HPV-positive cases, the result of inactivating RB by viral E7 protein. Another two mechanisms were found in the absence of HPV infection and involved silencing of the $\mathrm{p} 16^{\mathrm{INK} 4 \mathrm{~A}}$ gene followed by lack of $\mathrm{p} 16^{\mathrm{INK} 4 \mathrm{~A}}$ protein expression: one by promoter methylation, which they found in $15 \%$ of the carcinomas, the other by expression of the BMI-1 PcG gene detected in $10 \%$ of the carcinomas. Within their series there was only one case of verrucous carcinoma, and it was HPV6-positive, however, this tumour did not express p16 ${ }^{\mathrm{INK} 4 \mathrm{~A}}$ protein, exhibit p16 ${ }^{\mathrm{INK} 4 \mathrm{~A}}$ promoter methylation or BMI-1 staining, which suggests additional mechanism of $\mathrm{p} 16^{\mathrm{INK} 4 \mathrm{~A}}$ inactivation. Study by two of the authors of this paper $^{20}$ confirmed the inverse correlation between HPV16/18 and p16 ${ }^{\mathrm{INK} 4 \mathrm{~A}}$ in usual type squamous cell carcinomas and penile lichen sclerosus. We found the same correlation in our usual type samples but not in verrucous, which again suggests the connection to HPV infection only in usual type carcinoma.

Ki-67 protein is present during all active phases of the cell cycle $\left(G_{1}, S, G_{2}\right.$ and mitosis), but is absent from resting cells $\left(\mathrm{G}_{0}\right)$, which makes it an excellent marker for determining the so-called growth fraction of a given cell population. In our study, we detected significantly lower Ki67 expression in penile verrucous carcinomas than in usual type squamous cell carcinomas (67 and 93\%, respectively, $P=0.0108$ ). This expression was predominantly restricted to the basal layers. Very similar results have been reported in vulvar verrucous carcinoma, where Ki67 expression was present in $10-40 \%$ of cells, and in $70-80 \%$ of cases positivity was found in the basal layer of the neoplastic epithelium. ${ }^{3}$ Study of 19 cases of verrucous carcinoma from larynx, penis, oral mucosa and skin revealed the Ki67 staining in all verrucous carcinoma tumours and also only in basal and suprabasal cells, which was different from invasive squamous cell carcinomas, showing Ki67 expression diffusely throughout the whole malignant epithelium. ${ }^{37}$

\section{Conclusions}

Penile verrucous carcinoma, similar to other verrucous carcinomas, is a slow-growing tumour and this is reflected in the low Ki67 index. The lack of p16 ${ }^{\text {INK4A }}$ expression also differentiates these tumours biologically from usual type squamous cell carcinomas. The overexpression of p53 and RB proteins combined with the low incidence of p16 $6^{\mathrm{INK} 4 \mathrm{~A}}$ expression and HPV infection in verrucous carcinoma suggests that the virus plays a limited role in tumuorigenesis in this cancer type. Further studies on larger series are necessary to establish the significance of molecular changes in the development of the disease and their potential usefulness for designing treatment strategies.

\section{Acknowledgement}

This project is generously supported by The Jean Shanks Foundation and The Orchid Cancer Appeal.

\section{Conflict of interest}

None.

\section{References}

1 Ackerman LV. Verrucous carcinoma of the oral cavity. Surgery 1948;23:670-678.

2 Cuesta KH, Palazzo JP, Mittal KR. Detection of human papillomavirus in verrucous carcinoma from HIVseropositive patients. J Cutan Pathol 1998;25:165-170.

3 Gualco M, Bonin S, Foglia G, et al. Morphologic and biologic studies on ten cases of verrucous carcinoma of the vulva supporting the theory of a discrete clinicopathologic entity. Int J Gynecol Cancer 2003;13: 317-324.

4 Kraus FT, Perezmesa C. Verrucous carcinoma. Clinical and pathologic study of 105 cases involving oral cavity, larynx and genitalia. Cancer 1966;19:26-38.

5 Cubilla LC, Velazquez EF, Barreto JE, et al. The Penis Sternberg's Diagnostic Surgical Pathology, 4th edn Lippincott Williams \& Wilkins: Philadelphia, 2004;pp:2233-2276.

6 Velazquez EF, Cubilla AL. Penile squamous cell carcinoma: anatomic, pathologic and viral studies in 
Paraguay (1993-2007). Anal Quant Cytol Histol 2007;29:185-198.

7 Cubilla AL. The role of pathologic prognostic factors in squamous cell carcinoma of the penis. World J Urol 2009;27:169-177.

8 Cubilla AL. The penis In: Yong RH, Srigley JR, Amin MB, Ulbright TM and Cubilla AL (eds). Atlas of Tumor Pathology. Tumors of the Prostate Gland, Seminal Vesicles, Male Urethra, and Penis 3rd edn. Armed Forces Institute of Pathology: Washington, DC, 2000, pp 403-475.

9 Narayana AS, Olney LE, Loening SA, et al. Carcinoma of the penis: analysis of 219 cases. Cancer 1982;49:2185-2191.

10 Cubilla AL, Velazques EF, Reuter VE, et al. Warty (condylomatous) squamous cell carcinoma of the penis: a report of 11 cases and proposed classification of 'verruciform' penile tumors. Am J Surg Pathol 2000;24:505-512.

11 Cubilla AL, Reuter V, Velazquez E, et al. Histologic classification of penile carcinoma and its relation to outcome in 61 patients with primary resection. Int J Surg Pathol 2001;9:111-120.

12 Gregoire L, Cubilla AL, Reuter VE, et al. Preferential association of human papillomavirus with highgrade histologic variants of penile-invasive squamous cell carcinoma. J Natl Cancer Inst 1995;87:1705-1709.

13 Chan KW, Lam KY, Chan AC, et al. Prevalence of human papillomavirus types 16 and 18 in penile carcinoma: a study of 41 cases using PCR. J Clin Pathol 1994;47:823-826.

14 McKee PH, Lowe D, Haigh RJ. Penile verrucous carcinoma. Histopathology 1983;7:897-906.

15 Johnson DE, Lo RK, Srigley J, et al. Verrucous carcinoma of the penis. J Urol 1985;133:216-218.

16 Bunker CB. Topics in penile dermatology. Clin Exp Dermatol 2001;26:469-479.

17 Cubilla AL, Velazquez EF, Young RH. Epithelial lesions associated with invasive penile squamous cell carcinoma: a pathologic study of 288 cases. Int J Surg Pathol 2004;12:351-364.

18 Seixas AL, Ornellas AA, Marota A, et al. Verrucous carcinoma of the penis: retrospective analysis of 32 cases. J Urol 1994;152:1476-1478; discussion 1478-1479.

19 Sobin LH, Wittekind C. TNM Classification of Malignant Tumours 6th edn. Wiley-Liss: New York, 2002, p 239.

20 Prowse DM, Ktori EN, Chandrasekaran D, et al. Human papillomavirus-associated increase in p16INK4A expression in penile lichen sclerosus and squamous cell carcinoma. Br J Dermatol 2008;158:261-265.

21 Noel JC, Vandenbossche M, Peny MO, et al. Verrucous carcinoma of the penis: importance of human papillomavirus typing for diagnosis and therapeutic decision. Eur Urol 1992;22:83-85.

22 Kiyabu MT, Shibata D, Arnheim N, et al. Detection of human papillomavirus in formalin-fixed, invasive squamous carcinomas using the polymerase chain reaction. Am J Surg Pathol 1989;13:221-224.

23 Masih AS, Stoler MH, Farrow GM, et al. Penile verrucous carcinoma: a clinicopathologic, human papillomavirus typing and flow cytometric analysis. Mod Pathol 1992;5:48-55.

24 Pilotti S, Donghi R, D'Amato L, et al. HPV detection and p53 alteration in squamous cell verrucous malig- nancies of the lower genital tract. Diagn Mol Pathol 1993;2:248-256.

25 Haycox CL, Kuypers J, Krieger JN. Role of human papillomavirus typing in diagnosis and clinical decision making for a giant verrucous genital lesion. Urology 1999;53:627-630.

26 Villa LL, Lopes A. Human papillomavirus DNA sequences in penile carcinomas in Brazil. Int J Cancer 1986;37:853-855.

27 Varma VA, Sanchez-Lanier M, Unger ER, et al. Association of human papillomavirus with penile carcinoma: a study using polymerase chain reaction and in situ hybridization. Hum Pathol 1991;22: 908-913.

28 Higgins GD, Uzelin DM, Phillips GE, et al. Differing prevalence of human papillomavirus RNA in penile dysplasias and carcinomas may reflect differing etiologies. Am J Clin Pathol 1992;97:272-278.

29 Senba M, Kumatori A, Fujita S, et al. The prevalence of human papillomavirus genotypes in penile cancers from northern Thailand. J Med Virol 2006;78:1341-1346.

30 Lam KY, Chan AC, Chan KW, et al. Expression of p53 and its relationship with human papillomavirus in penile carcinomas. Eur J Surg Oncol 1995;21: 613-616.

31 Cupp MR, Malek RS, Goellner JR, et al. The detection of human papillomavirus deoxyribonucleic acid in intraepithelial, in situ, verrucous and invasive carcinoma of the penis. J Urol 1995;154:1024-1029.

32 Kleter B, van Doorn LJ, ter Schegget J, et al. Novel short-fragment PCR assay for highly sensitive broadspectrum detection of anogenital human papillomaviruses. Am J Pathol 1998;153:1731-1739.

33 Rubin MA, Kleter B, Zhou M, et al. Detection and typing of human papillomavirus DNA in penile carcinoma: evidence for multiple independent pathways of penile carcinogenesis. Am J Pathol 2001;159:1211-1218.

34 Koyamatsu Y, Yokoyama M, Nakao Y, et al. A comparative analysis of human papillomavirus types 16 and 18 and expression of p53 gene and Ki-67 in cervical, vaginal, and vulvar carcinomas. Gynecol Oncol 2003;90:547-551.

35 Lam KY, Chan KW. Molecular pathology and clinicopathologic features of penile tumors: with special reference to analyses of p21 and p53 expression and unusual histologic features. Arch Pathol Lab Med 1999;123:895-904.

36 Ouban A, Dellis J, Salup R, et al. Immunohistochemical expression of $\mathrm{Mdm} 2$ and p53 in penile verrucous carcinoma. Ann Clin Lab Sci 2003;33:101-106.

37 Adegboyega PA, Boromound N, Freeman DH. Diagnostic utility of cell cycle and apoptosis regulatory proteins in verrucous squamous carcinoma. Appl Immunohistochem Mol Morphol 2005;13: 171-177.

38 Hall PA, McCluggage WG. Assessing p53 in clinical contexts: unlearned lessons and new perspectives. J Pathol 2006;208:1-6.

39 Roninson IB. Oncogenic functions of tumour suppressor p21(Waf1/Cip1/Sdi1): association with cell senescence and tumour-promoting activities of stromal fibroblasts. Cancer Lett 2002;179:1-14.

40 Harris SL, Levine AJ. The p53 pathway: positive and negative feedback loops. Oncogene 2005;24: 2899-2908. 
41 Missero C, Calautti E, Eckner R, et al. Involvement of the cell-cycle inhibitor Cip1/WAF1 and the E1A-associated p300 protein in terminal differentiation. Proc Natl Acad Sci USA 1995;92: 5451-5455.

42 Cheung TH, Lo KW, Yu MM, et al. Aberrant expression of p21(WAF1/CIP1) and p27(KIP1) in cervical carcinoma. Cancer Lett 2001;172:93-98.

43 Tron VA, Tang L, Yong WP, et al. Differentiationassociated overexpression of the cyclin-dependent kinase inhibitor p21waf-1 in human cutaneous squamous cell carcinoma. Am J Pathol 1996;149:1139-1146.

44 Nevins JR. The Rb/E2F pathway and cancer. Hum Mol Genet 2001;10:699-703.

45 Serrano M. The tumor suppressor protein p16INK4a. Exp Cell Res 1997;237:7-13.
46 Sano T, Oyama T, Kashiwabara K, et al. Expression status of p16 protein is associated with human papillomavirus oncogenic potential in cervical and genital lesions. Am J Pathol 1998; 153:1741-1748.

47 Ferreux E, Lont AP, Horenblas S, et al. Evidence for at least three alternative mechanisms targeting the p16INK4A/cyclin $\mathrm{D} / \mathrm{Rb}$ pathway in penile carcinoma, one of which is mediated by high-risk human papillomavirus. J Pathol 2003;201:109-118.

48 Dianzani C, Bucci M, Pierangeli A, et al. Association of human papillomavirus type 11 with carcinoma of the penis. Urology 1998;51:1046-1048.

49 Wong M, Walzman M, Zayyan K, et al. Verrucous carcinoma - an embarrassing problem? Int J STD AIDS 2007;18:573-574. 